\title{
Shadow Kingdom: Lotharingia and the Frankish World, c.850-c.1050
}

\section{Introduction}

Like any family, the Carolingian dynasty which ruled continental Western Europe from the mid-eighth century until the end of the ninth had its black sheep. Lothar II (855-69) was perhaps the most tragic example. A great-grandson of the famous emperor Charlemagne, he belonged to a populous generation of the family which ruled the Frankish empire after it was divided into three kingdoms - east, west and middle - by the Treaty of Verdun in 843. In 855 Lothar inherited the northern third of the Middle Kingdom, roughly comprising territories between the Meuse and the Rhine, and seemed well placed to establish himself as a father to the next generation of Carolingians. But his line was not to prosper. Early in his reign he had married a noblewoman called Theutberga in order to make an alliance with her family, but a few childless years later attempted to divorce her in order to marry a former lover called Waldrada by whom he already had a son. This was to be Lothar's downfall, as his uncles Charles the Bald and Louis the German, kings respectively of west and east Francia, enlisted the help of Pope Nicholas I in order to keep him married and childless, and thus render his kingdom vulnerable to their ambitions. In this they were ultimately successful - by the time he died in 869, aged only 34, Lothar's divorce had become a full-blown imperial drama played out through an exhausting cycle of litigation and posturing which dominated Frankish politics throughout the 860s. ${ }^{1}$ In the absence of a legitimate heir to take it over, his kingdom was divided between those of his uncles - and with the exception of a short period in the 890s, it never truly existed again as an independent kingdom.

Like many other transient polities before and after, Lothar's realm should by rights have been swallowed up by the ever-shifting plates of European political history, never to be seen again. But, remarkably, this did not happen. Although it was divided again and again between neighbouring kingdoms (seven times already by 880), the unfortunate king's name somehow stuck to the region he had ruled, first as 'Lothar's kingdom' ('regnum Lotharii'), and from the middle of the tenth century - by which time it had become a duchy of the east Frankish kingdom - as 'Lotharingia'. 2 The name is fossilised today in the French administrative region Lorraine (German: Lothringen). As part of Alsace-Lorraine this region has played a famous role in modern European history as a 'victory trophy' in Franco-German conflicts since the early modern period, and especially since $1871 .^{3}$ Lothar II's spectre was explicitly resurrected in the wartime deliberations of the politicians who would go on to shape the European Union: the French government in exile in Algiers discussed Lotharingia as a potential historical reference point for a postwar European order embracing the contiguous heartlands of France, Belgium, Luxembourg, the Netherlands and, later, Germany. ${ }^{4}$ In the end Charlemagne was preferred as the symbolic 'father of Europe', to appeal to a more conventional and betterknown narrative of European origins. ${ }^{5}$ Lothar thus retreated back into the shadow of his illustrious ancestor, though not into total obscurity: the so-called 'Great Region' set up in the 1970s and centred on Luxembourg, Lorraine and the Saarland also revived memories of the early medieval past - a competition to find a name for the region held in 2002 included 'Lotharingia' on the shortlist. ${ }^{6}$ Alas, it did not win - Lothar II, tormented by popes and uncles while he lived, was thwarted once again by posterity. 
These recent invocations of Lotharingia as a historical touchstone for a transnational version of European political organisation were prompted by the industrial significance of the region, particularly its coal and steel production. This economic importance was nothing new. The region's broad rivers, central location, healthy agricultural productivity and population density meant it had a consistent role in the big picture of European history, and it has been argued that these factors exerted a gravitational force on the shapes of Philip the Good's Burgundy, Napoleon's empire, and the so-called 'Blue Banana' of modern economic geographers. ${ }^{7}$ In the Middle Ages its logistical and economic centrality was also translated into cultural attitudes which found expression in notions of 'heartland and border', as Robert Bartlett has shown. ${ }^{8}$ A case could therefore be made that Lotharingia has in a sense always existed, as a recurrent product of the interchange between human activity and European geography - and that Lothar's kingdom was thus simply one manifestation of a deeper-rooted historical reality.

But neither modern reinventions of Lotharingia as a historical entity, nor the possibility of longue durée currents holding it together under the surface, can obscure the fact that the political history of the region, on which this article concentrates, was highly discontinuous. This is part of what makes it so interesting, and why it has attracted such a vast quantity of scholarly attention: in $1833 \mathrm{E}$. Bégin estimated that there were already around 1,200 titles on the topic, and that was over sixty years before the appearance of what is today regarded as the seminal work by Robert Parisot, which has in turn inspired several generations of further studies. ${ }^{9}$ Lotharingian history also has a dedicated book series, the 'Journées Lotharingiennes', established in the 1980s as a means of positioning the history of Luxembourg in an international context. ${ }^{10}$ Still, the bewildering array of scholarship on the middle Frankish kingdom does carry less historiographical baggage than the eastern and western Frankish kingdoms, which have often been seen as prototypes for France and Germany. ${ }^{11}$ Since we know it had no future as a nation-state, the middle kingdom is perhaps easier for us to examine as an artefact of its own time. Lotharingia, then, is a useful lens through which we can try to observe the confusing and contested politics of the late- and post-Carolingian age in the ninth and tenth centuries - a period which witnessed the end of the age of great European empires and the beginnings of medieval Europe. ${ }^{12}$ We will first survey the history of Lotharingia's relations with its neighbours; and then look at questions of authority and identity within the region itself.

\section{Between east and west: what was Lotharingia?}

The easiest way to describe the boundaries of Lothar II's kingdom is in terms of rivers: to the east it was bounded by the Rhine and to the west by the Scheldt and the Meuse. Its southern frontier abutted Burgundy. But nature did as much to interrupt as to confirm the kingdom's definition - the hills and forests of the Ardennes, for instance, divided its northern ('Lower') and southern ('Upper') parts. Ecclesiastical and secular definitions of territory breached the rivers on both sides - thus the dioceses of Toul and Verdun extended west of the Meuse, while some counties stretched east of the lower Rhine. ${ }^{13}$ The human boundaries shifted constantly as pieces were added to and removed from the kingdom by the vagaries of political circumstance. Nor did its shape correspond to obvious cultural frontiers - the Romance/Germanic linguistic split ran through 
Lotharingia rather than along one of its edges. ${ }^{14}$ Instead, the primary purpose of the regnal division that created Lothar's kingdom was the fair division of resources between members of the Carolingian family. Coal and steel lay in the future, but in contemporary terms the region's economic resources were considerable. Dorestad, which lay in Frisia near the mouth of the Rhine, was a major trading node of the Carolingian period and although it was on the wane by the later ninth century we know that Frisia remained an important North Sea trading centre in the tenth and eleventh centuries. ${ }^{15}$ The decline of Dorestad was linked to the rise of new trading hubs further up-river, not least among them Verdun on the Meuse, a long-standing commercial centre which contemporary observers linked with long-distance slave trading to the Mediterranean littoral. ${ }^{16}$ More mundane commodities included the agricultural surpluses produced by the kingdom's large and land-rich monasteries such as Prüm. ${ }^{17}$ The increase in our period in the size of the marketplace at Cologne, revealed by archaeology, implies that the regional circulation of goods was an increasingly important feature of Lotharingian life in the later ninth and tenth centuries. ${ }^{18}$

The region's ruling families certainly benefited from such activity. An example of this is the incipient and expensive trend of aristocratic strongholds built in stone referred to in tenth-century sources. ${ }^{19}$ Alpert of Metz, writing in the early 1020s, describes an aristocratic dispute in which the superior wealth of one party was due to his holding more lands than his rival on the left of the Rhine - the implication being both that he had access to the river's commerce, and that land in 'Gallia' (Lotharingia) was somehow more valuable than land in 'Germania'. ${ }^{20}$ Economic vitality did not necessarily lead to political stability - Alpert's story clearly shows that resources were a focus of conflict as well as a source of wealth. Similarly, early medieval kings did not always find it easy to benefit directly from their kingdoms' wealth: in 856 Lothar II claimed that the 'diminution of the kingdom' had forced his father to take lands from the church. ${ }^{21}$ But while Lotharingia was relatively small by Carolingian standards, it did have a spectacular concentration of political resources which its rulers could seek to manipulate, including two archbishoprics, eight bishoprics and numerous imperial monasteries which served as centres of wealth, commemoration and elite socialisation. Among them were several archetypal dynastic centres like Aachen, the site of Charlemagne's most famous palace, and Metz, the final resting place of Lothar's grandfather Louis the Pious and of Bishop Arnulf, the legendary progenitor of the Carolingians. Little wonder that in the thirteenth century Lotharingia could be referred to as 'patria regum': homeland of kings. ${ }^{22}$

These potent royal sites were a major reason why control of Lotharingia became such a driving ambition for the kings of east and west Francia after the middle of the ninth century. ${ }^{23}$ Lothar II's death in 869 flipped the cold-war posturing of the previous decade over into open confrontation between his uncles: Charles the Bald marched to Metz and had himself crowned in September, though soon afterwards he was forced to back down when his brother Louis the German threatened military action of his own. The outcome was the Treaty of Meersen of 870, which divided Lotharingia into east and west, each part apparently dissolved into its large neighbours on either side. Charles tried to push his frontier eastwards after his brother's death in 876, but a decisive victory won by Louis the Younger, Louis the German's son, confirmed the Meersen geography. Another 
dynastic conflict soon after resulted in the whole of Lotharingia being ceded to the east Frankish kingdom of Louis the Younger in the Treaty of Ribemont (880), though there is some evidence that at times it was still seen as an area of joint responsibility between the parties. $^{24}$ However, the premature deaths of eight rulers between 875 and 884 rendered any such agreements moot, and left Charles III 'the Fat' to rule the empire alone. It was a task he was not up to, and when he was deposed in late 887, to die a few weeks later in January 888, he left behind no legitimate heirs. Devoid of adult male Carolingians to rule it, the Carolingian Empire splintered and control of its constituent kingdoms was taken up by kings from powerful aristocratic families. Crucially, though, these new rulers were not related to each other, and (as contemporaries noted) none of them was strong enough to dominate the others. ${ }^{25}$ The familial and ideological glue which had held it together was thus gone, and the Carolingian Empire de facto ceased to exist. ${ }^{26}$

Lotharingia remained part of the east Frankish kingdom, ruled by the most powerful of the new kings, Arnulf, an illegitimate grandson of Louis the German, whose control was confirmed in 892 at the River Dyle (in northern Lotharingia) by a famous victory over Scandinavian armies. But despite this successful early foray into the northwest of his realm Arnulf's power-base was in Carinthia, far from the old royal heartlands of the Carolingians, and his imperial ambitions meant that he was more interested in Italy than in the north and west of his kingdom. His influence in Lotharingia became vulnerable to the raids of Charles 'the Straightforward' (or 'Simple'), a grandson of Charles the Bald who had been passed over in 888 on account of his youth, and by murderous conflicts between local aristocratic families. He sought to stabilise the situation in 895 by installing his son Zwentibald as king - the only man apart from Lothar II to rule Lotharingia as a kingdom - but the factionalisation of local politics meant that he was unable to rule effectively and gained a reputation for unpredictability and instability. ${ }^{27}$ In 900, Zwentibald himself was killed in a conflict with aristocratic rivals. His half-brother Louis the Child, king of east Francia, then took over. When Louis died, childless, in 911, aged only 18, Arnulf's line was extinguished, and with it the last vestiges of Carolingian authority in east Francia: 'the royal line', as one mid-tenth century observer put it, 'had now failed'. ${ }^{28}$

Either slightly before or immediately after Louis died, 'the Lotharingians', as some contemporaries had now begun to call them, transferred their allegiance to Charles the Straightforward, who had become king of west Francia in 898. Charles lacked the resources of his Carolingian ancestors and could not rule like them, and by way of compensation he took every opportunity to assert the prestige of his family background: but it was only after he took over Lotharingia, with its distinctive royal topography, that he felt able to adopt Charlemagne's hegemonic title 'rex Francorum' ('king of the Franks'). ${ }^{29}$ Charles also worked hard to integrate Lotharingia into his west Frankish kingdom, using the connections afforded by his Lotharingian wife Frederun to make alliances with important aristocratic figures there, and seeking to influence episcopal appointments. $^{30}$ In 921 the new king of east Francia, Henry I (first ruler of the Ottonian dynasty), met Charles at Bonn, thus tacitly confirming that the Rhine was the frontier between their kingdoms and that Lotharingia belonged to the west. However, Charles's keen interest in Lotharingia seems to have been one of the reasons that leading west 
Frankish figures lost patience with him. In 922 he was deposed, in 923 imprisoned, and he died in 929. By then, in 925, 'the Lotharingians' had transferred allegiance again, to the eastern kingdom of Henry I, who sought to cement the alliance by marrying his daughter Gerberga to the leading magnate in the middle kingdom, Giselbert. ${ }^{31}$ This time the switch was permanent: it would be another seven centuries before Lotharingia (or at least the southern half which became Lorraine) was ruled again from France.

Nonetheless, we should be careful not to let hindsight obscure our view: as Joachim Ehlers has stated, the struggle for Lotharingia remained the central issue in tenth-century dynastic politics even after $925 .^{32}$ A major rebellion against Otto I shortly after his accession in 936 involved the leading magnates of Lotharingia, and led to an invasion by Louis IV, Charles the Straightforward's son and successor. Although Otto prevailed, Louis then married his sister Gerberga, widow of Giselbert of Lotharingia: their first son, born in 941, was pointedly named Lothar. Like his father, Louis IV faced severe opposition inside his kingdom, so his expansionary ambitions were never realised. Still, the intermediaries installed by Otto as dukes in the region did not have things their own way, and the second major rebellion against the king, in 953-4, again centred on Lotharingia. ${ }^{33}$ Gerberga and Lothar's public renunciation of their Lotharingia aspirations in 959 arguably represented a continuation rather than a cessation of the struggle for the middle kingdom, as it served equally as an open declaration that they nurtured claims to a territory which had never really been theirs. ${ }^{34}$ Hot conflict flared again in 978, when Lothar took Aachen and briefly held it - Richer of Rheims says that he turned the eagle on roof of the palace to point east, symbolising his claims to Lotharingia as a whole before Otto II reversed his losses with a massive retaliatory raid. ${ }^{35}$ The two kings made peace just east of the Meuse in 980 - significantly, a long way west from where Charles the Straightforward and Henry I had met in 921. Upon Otto II's death in 983 Lothar tried his luck again, capturing various Lotharingian magnates, taking the great commercial centre of Verdun, and holding it for over a year.

This phase of conflict came to an end with Lothar's death in 986 and that of his son Louis $\mathrm{V}$ a year later. The next west Frankish king, Hugh Capet, was from a new dynasty and although his family - the Capetians - did retain a residual claim to Lotharingia which was occasionally backed with force, they did not pursue it with as much vigour as their predecessors. The accession of the Capetians gave Hugh's contemporary Otto III an opportunity to assert control of Lotharingia and its Carolingian heritage with much more confidence than previous Ottonian kings. ${ }^{36}$ There is also a sense in west Frankish texts of the earlier eleventh century that Lotharingia had been lost - that west Frankish aspirations there were real, but lay in a regretted past rather than a realisable future. ${ }^{37}$ This does not mean that subsequent east Frankish kings had it all their own way - both Henry II (1002-24) and Conrad II (1024-39) had to resort to military force to establish their right to rule in Lotharingia against local opposition. ${ }^{38}$ However, it is arguably the case that the mid-eleventh century marked the end of its formal history, and of the pattern of tug-of-war politics initiated by the reign of Lothar II: then it was that the duchy was definitively divided into northern (Lower) and southern (Upper) halves. ${ }^{39}$ 
Conflict for Lotharingia between the kings of east and west Francia was thus the hallmark of its history from its beginnings in the mid-ninth century until at least the end of the tenth. However, it would be a mistake to see in this pattern (as many have done) an expression of primordial Franco-German rivalry, foreshadowing modern disputes over Alsace-Lorraine. Instead, we need to understand it as a product of contemporary political circumstances, especially those pertaining after the end of the Carolingian monopoly on royal power in 888 . None of the kings who ruled after this date, even those descended from the ninth-century Carolingians, could expect to have their legitimacy accepted as a matter of course. They had to compete not just to dominate their rivals, but even to establish the very notion of their own regality. In this struggle for legitimacy, attempts to appropriate the symbolic capital of Lotharingia's Carolingian past played an important role. Otto I, for example, sought to enhance his family's prestige by furnishing their main religious houses with relics from Carolingian churches in the middle kingdom such as Maastricht and Cambrai. ${ }^{40}$ Likewise, Charlemagne's palace and chapel at Aachen were ostentatiously imitated by rulers seeking to buy into its history by association, and to divert its glamour towards distant regions such as Saxony, Alsace and Flanders. ${ }^{41}$

Such symbolic one-upmanship reflected the fact that the heartlands of the tenth-century dynasties were far from the core territories of the old Carolingian Empire: Charles the Straightforward and his descendants lacked authority beyond Laon and Rheims, the Capetians were based in Tours and Paris, while the Ottonian heartlands were in Saxony and (after 1002) Bavaria. Lotharingia was thus simultaneously central in political/cultural terms and peripheral in a geographical sense. This paradox fuelled conflict over the kingdom, its physical unattainability making it hard to definitively control and causing its symbolic significance to inflate. ${ }^{42}$ Yet the resulting conflict also provided repeated opportunities to define, classify and therefore assert the region's identity as a region. The intensity of the struggle for Lotharingia between its neighbours, each operating at the fingertips of their reach, was what burned its shadow onto the map of Europe.

\section{Identity and authority}

Lotharingia figures prominently not just in discussions about interaction between the Frankish kingdoms, but also in a set of debates about identity and authority within them. These debates, which have long dominated German historiography on tenth-century political history, are prompted by the emergence in the post-Carolingian kingdoms of sub-regnal units called duchies or principalities. Arguments about the character of the duchies have turned on two issues in particular: were they in any sense 'ethnic' communities, or were they administrative units produced by Carolingian politics? and how did the 'dukes' mediate between duchy and king - as autonomous leaders of the former, or appointed representatives of the latter? These questions feed in different ways into the master narratives of French, German and Italian history, and much of the modern historiography on the topic deals explicitly or implicitly with the origins of modern nations. ${ }^{43}$ Although it does not fit conveniently into these national narratives, assertions about the coherence or otherwise of the Lotharingian duchy have nonetheless been influenced by the political prejudices of the twentieth. ${ }^{44}$ Also at stake here are competing models of Europe's transition from the post-Roman age of large empires to a Middle 
Ages characterised by the privatisation of judicial institutions, the intensification of local lordship and the domination of the peasantry through coercion and violence. Some historians place this transformation in a 'Feudal Revolution' in the decades around 1000, while others argue that the change was much slower, or even that there was not much change at all. ${ }^{45}$ Although evaluation of this debate is beyond the scope of the present article, we should note that the evidence for Lotharingian ducal power and collective identity has played an integral role in its unfolding. ${ }^{46}$

That evidence is so interesting and contested in part because it is fragmented and hard to understand. In contrast to the rich annalistic tradition of the Carolingian era, the first half of the tenth century produced few extended narrative sources. The situation improves after 950, but we are forced to look at Lotharingia primarily through the eyes of authors based in east and west Francia. The longer-form texts we do have are mainly hagiographical, telling sacred histories of monasteries and bishoprics rather than recounting events in the kingdom as a whole. As Theo Riches has recently argued, this pattern of evidence can be interpreted as a historical fact in itself - uncertainty about the political centre meant that major churches became the main focuses of institutional memory, preserving and re-framing elements of Carolingian political culture in a completely new environment. ${ }^{47}$ Otherwise, we can turn to a large body of royal and nonroyal charters - documents recording gifts of property and privilege to individual churches, which often include crucial nuggets of information about the geographies and idioms of political power. Inferences about ducal authority and collective identity have to be sifted carefully from such material. The problem is not so much a lack of evidence per se as a lack of agreement about what kind of picture the finished jigsaw should reveal - or even about how many different jigsaws we should be trying to make. ${ }^{48}$ However, the linked questions of authority and identity undoubtedly do take us to the heart of some distinctive features of tenth-century Europe.

Firstly, who were the dukes and how should we understand their role? The Latin title $d u x$ simply means 'leader'. The ninth-century Carolingians were careful only to use it in military contexts and never to designate a regular office or role - for them, the term carried uncomfortable echoes of the powerful rivals they had had to overcome during their rise to power in the eighth century. The post- 888 usage was different, as revealed by an early example in a charter of Louis the Child from 903, in which the powerful aristocrat Gebhard is described as ' $d u x$ of the kingdom which many call Lothar's' ${ }^{49}$ One reading of this would be that Gebhard was the king's formally-appointed representative in Lotharingia. Certainly, several other powerful figures were referred to as $d u x$ in the area in the course of the tenth century, and only ever one at a time. Some at least are reported to have been installed by the Ottonians. In 953, for example, Flodoard of Rheims states that Otto I 'removed Conrad [the Red] from the duchy of Lotharingia' after a rebellion and replaced him with his own brother, archbishop Brun of Cologne. ${ }^{50}$ Sources from the end of our period are even more emphatic about the formality of the ducal role: thus, for instance, the late-eleventh century 'Translation of St Servatius' describes Giselbert (d. 939) as ruling Lotharingia 'on behalf of the emperor'. 51 
Projecting such an institutional perspective back into the tenth century may be misleading. In an important book published in 1977 Hans-Werner Goetz powerfully attacked the old view of the post-Carolingian dukes as intermediary officials, emphasising that their reach was often limited within their supposed spheres of influence, and that their interests also extended beyond the frontiers of the 'duchies' - that they were not a completely new phenomenon so much as repackaged versions of ninth-century 'imperial aristocrats'. 52 What's more, these men were not titled 'dux' consistently, and were just as likely to be referred to by contemporaries as 'comes' (count) or 'marchio' (powerful count). More recent studies by Rüdiger Barth and Jens Schneider have taken an equally sceptical view with regard to Lotharingia in particular. ${ }^{53}$ Nonetheless, in scholarship on this period the tacit assumption persists that the equation of duke and duchy was a straightforward and fundamental building block of the post-Carolingian world.

Posed in such stark terms, there is no simple way to resolve this question - the formality or otherwise of the ducal 'office' will depend on the assumptions one brings to the question. But more nuanced insights have been gained by looking at what these ducal figures actually did, and by focusing on the differences between them rather than trying to isolate what they had in common. Giselbert was arguably the most powerful of the Lotharingian dukes. It has been argued that he may even have sought to have himself crowned king in 920: the issue turns on Flodoard's use of the unusual term 'princeps', and the weight of opinion is currently against. However, his career underlines the extreme fluidity of political hierarchies in the earlier part of the century. He was influential enough to bring the loyalty of 'the Lotharingians' to Henry I in 925, and the king recognised his status by giving the hand of his daughter Gerberga in 928 and consistently referring to him as 'dux' thereafter. A charter of 934 calls Giselbert and his associates 'leaders of Lothar's kingdom'. ${ }^{54}$ What he hoped to gain from his rebellion against Otto I in 938-9 we can only guess, though his death in the course of it was a great relief to the king and the campaign of damnatio memoriae to which his reputation was then subjected implies that he was considered a formidable rival. ${ }^{55}$ Giselbert is also one of the few leaders of northern Lotharingia who is known to have had some influence in the south, at the important nunnery of Remiremont. ${ }^{56}$ But even Giselbert did not have it all his own way. He had rivals in the south, such as the powerful Count Boso whose resistance to the duke's ambitions is described in the Life of John of Gorze. ${ }^{57}$ When we examine Giselbert's career closely, he looks like an unusually powerful factional leader whose evident influence was based on a range of factors, including his family's historic standing, his ability to play the eastern and western kings against each other, and his control of a network of reformed monasteries through which political power could be projected. ${ }^{58}$ His 'ducal' status was not an independently-defined official position, but another aspect of his political persona - we might well say that he was duke because he was powerful, rather than the other way round.

From the late 940s it does look as if Otto I attempted to formalise the notion that dukes were appointed by the king, and simultaneously sought to keep them close by installing men who were closely related to him by blood or marriage. But this does not seem to have done much for his son-in-law Conrad 'the Red', whose attempts in the early 950s to 
call the shots as Otto's representative in Lotharingia soon dissolved into chaos as indigenous magnates refused to do his bidding, driving him into rebellion and a desperate alliance with pagan Hungarian mercenaries. Even Otto's brother Brun of Cologne struggled to impose himself as $d u x$, facing severe opposition not just from his sister Gerberga, but also from local potentates such as Reginar III, Giselbert's nephew. ${ }^{59}$ A text written in Utrecht during his lifetime even seems to reject the notion of allegiance to the Ottonians altogether. ${ }^{60}$

By the later tenth century there are signs that the balance of powers was stabilising. By 1000 the aristocratic families who controlled the main political offices and resources in southern Lotharingia (notably the family known to historians as the 'Ardenner') were those who would continue to do so for some centuries. ${ }^{61}$ By the 980 s we even find a woman (Beatrice, widow of Duke Frederick) holding the masculine title $d u x$, which implies that the position had been reified and depersonalised to some degree. ${ }^{62}$ And the Miracles of St Gorgonius, written at Gorze in the 980s, includes a passage which implies that the duke was perceived as responsible by virtue of his position for the protection of monasteries he did not control personally (though the point of the story is to criticise him for not doing so). ${ }^{63}$ But we also find in the Chronicle of St-Mihiel, 50 years later, a duke forcibly appropriating an important Lotharingian monastery because it was 'far from royal authority'. ${ }^{64}$ Even in the mid-eleventh century the factional and formal identities of the dukes, their official and aristocratic personas, could still be perceived as inseparable.

Such caveats about the coherence and consistency of ducal office also have implications for the other part of the debate on the duchies, namely the definitions of the community over which they were said to rule. The idioms of political power in the early Middle Ages drew heavily on ethnic discourses - thus the ninth-century Carolingian kings were often defined as 'kings of the Franks'. Kings were generally loathe to endow the analogous prestige of an ethnic qualifier on the tenth-century dukes - Giselbert was only once called 'duke of the Lotharingians' in a royal charter, which was issued at the beginning of Otto I's reign when he was desperate to curry favour. ${ }^{65}$ The commonlyused expression for the region in the later ninth century was, as we noted at the beginning, 'regnum Lotharii' - Lothar's kingdom. The term 'Lotharingians' does not appear before the second decade of the tenth century; and for the first use of 'Lotharingia' we have to wait until Liudprand of Cremona's Book of Retribution, written at the end of the 950s. ${ }^{66}$ The historians of Otto I's reign were the first to ascribe characteristics to the Lotharingians: Widukind of Corvey, for example, wrote that they were 'a skilful people, accustomed to ingenuity and ready for warfare' ${ }^{67}$ This is a curious evolution - as Tim Reuter pointed out, it was unusual for a people to be named after their king, rather than the other way round. ${ }^{68}$ The question of what was meant by these terms for the territory and the people who lived there has thus proved enduringly controversial.

For some historians it is axiomatic that Lotharingia (and the Lotharingians) had a continuous history from the time of Lothar II onwards, not least because the 'regnum Lotharii' is referred to fairly regularly by late ninth-century authors even when it was divided. The presumption that a persistent sense of regnal coherence lay behind such 
terminology has led to its use as an explanation for key moments in political history. Thus it has been suggested that the failed rebellion of Hugh, Lothar II's son, who sought to regain the 'paternal kingdom' in 883 , was backed by aristocrats who had a stake in and residual loyalty to a reconstituted Lotharingia. ${ }^{69}$ Similarly, Zwentibald is sometimes thought to have cemented the notion of Lotharingian identity inadvertently, by uniting the region's nobles against him. Various mechanisms and forums have been adduced by which such an identity might have been fostered and transmitted, among them the numerous gatherings of Lothar's bishops during his divorce case; the regular meetings of Carolingian kings in the middle kingdom in the later ninth century; and the maintenance of a separate 'chancery' network and distinct royal titulature by kings either side of $900 .^{70}$ Thomas Bauer has gone further, arguing that Lotharingia constituted a distinctive cultural space even in the longue durée, defined not just by political structures but also by particular forms of religious devotion. ${ }^{71}$

But, at the moment, the balance of opinion seems to be against such a view. Stuart Airlie has recently argued, convincingly, that Lothar II was not a cause célèbre so much as an embarrassment to his bishops and aristocrats. ${ }^{72}$ This was still the case for Regino of Prüm, the great Lotharingian chronicler of the late Carolingian age, who does not so much as acknowledge the idea of a Lotharingian regnal identity and has nothing good to say about either of the Lotharingian kings, Lothar II and Zwentibald. ${ }^{73}$ Taking issue with Bauer's thesis, Jens Schneider and Michel Margue have argued strongly that the mechanisms one would need to sustain a continuous sense of political togetherness (including a stable political centre, central places, rituals and regalia symbolizing rulership, a clear definition of space, a sense of shared history) were all but completely lacking in the ninth and tenth centuries. ${ }^{74}$ Lotharingian history was rewritten, or even created, only by the episcopal ideologues of the eleventh century - at precisely the point when the unified duchy ceased to exist. ${ }^{75}$

It might be said that these arguments 'against' seem strong because deconstructing Lotharingian identity is easier than describing it - the evidence lends itself more readily to being pulled apart than drawn together. Whether or not that is the case, historians' positions on the coherence or otherwise of a Lotharingian regnal community are clearly very polarised. But when asking ourselves whether this particular glass is half-full or half-empty, we should also ask what we mean by the 'identity' we are trying to locate. Above all, we need to be wary of exporting modern notions of nationality and belonging: early medieval concepts of ethnicity, unlike our own, were tacitly but deeply influenced by biblical discourses about conversion and salvation. ${ }^{76}$ Moreover, ethnic labels could be relational - the surfacing of the usage 'kingdom of the Teutons' for east Francia in the late tenth century was a response to the Ottonians' incorporation of Italy into their realm; and likewise the emergence of 'Lotharingia' and 'Lotharingians' coincides with the increasing restriction of the ubiquitous ninth-century label 'Francia' to the royal heartlands of west Francia. ${ }^{77}$ Such shifts suggest that ethnic labels did not necessarily correlate straightforwardly to communities of feeling - ethnic classification was (and is) an aspect of political discourse, and was sometimes used by contemporaries in pointed, rhetorical ways. ${ }^{78}$ Beyond the long-running debate about the existence or otherwise of Lotharingia as a cultural space and imagined community, this evidence may therefore 
still have something useful to tell us about the fragmentation of Carolingian political order and its reconstitution in the new idioms of the post-Carolingian era.

\section{Conclusion}

The political history of Lotharingia in the ninth and tenth centuries was sui generis - its 'in-between' geographical position combined with its rich political traditions made it an object of desire for rulers near and far, and the interplay between them created the fragmented history we have considered in this article. But in other ways, the problems of understanding Lotharingian history give us useful general insights into the late- and postCarolingian world. Its obvious constructedness and discontinuousness, its provisional character, should serve as a cautionary tale for anyone studying the early history of its neighbouring kingdoms, which later became France and Germany. That such an artificial and provisional political unit as Lotharingia, whose boundaries were defined by immediate political circumstances rather than any deep-rooted cultural or geographical factors, could become within a few generations the home of a 'people' to whom national characteristics were ascribed is generally seen as a surprising feature which demands explanation. But maybe this is looking at the picture in negative. If we suppose that Lotharingia's course of development was representative of early medieval politics, rather than odd, we are compelled to confront some of the tacit assumptions habitually made about the origins of other European nations. There is no reason to think that Lotharingia's historical cul-de-sac was inevitable, nor that the same fate could not have befallen instead its more familiar-looking neighbours. All these political units were in a state of constant change, their boundaries and their identities subject to a process of perpetual reinvention. This makes the origins of Europe much less certain and much more interesting. In this context, the idea that Lothar II's kingdom was somehow a forerunner of a post-national European Union is no more implausible than the idea that Charles the Bald and Louis the German were the first kings of France and Germany. ${ }^{79}$

\footnotetext{
${ }^{1}$ S. Airlie, 'Private Bodies and the Body Politic in the Divorce Case of Lothar II', Past and Present, 161 (1998): 3-38; K. Heidecker, The Divorce of Lothar II: Christian Marriage and Political power in the Carolingian World, trans. T.M. Guest (Ithaca: Cornell University Press, 2010).

2 J. Schneider, 'Spacing Lotharingia. Zum Problem des lothringischen Raumes' , forthcoming, emphasises the number of divisions.

${ }^{3}$ C.J. Fischer, Alsace to the Alsatians? Visions and Divisions of Alsatian Regionalism, 1870-1939 (New York and Oxford: Berghahn Books, 2010), 2; C. Fischer, Europe Between Democracy and Dictatorship, 1900-1945 (Chichester: Wiley-Blackwell, 2011), 130-2.

${ }^{4}$ J. Monnet, Memoirs, trans. R. Mayne (London: Collins, 1978), 221-2; F.J. Fransen, The Supranational Politics of Jean Monnet. Ideas and Origins of the European Community (Westport and London: Greenwood Press, 2001): 89-91, 95-6.

${ }^{5}$ As articulated by de Gaulle in 1950: Monnet, Memoirs, 287.

${ }^{6}$ P. Péporté, S. Kmec, B. Majerus and M. Margue, Inventing Luxembourg. Representatives of the Past, Space and Language from the Nineteenth to the Twenty-First Century (Leiden: Brill, 2010), 214-15.

${ }^{7}$ J. Schneider, 'Lotharingie, Bourgogne ou Provence? L'idée d'un royaume d'Entre-Deux aux derniers siècles du moyen âge', in Liège et Bourgogne (Paris: Les Belles Lettres, 1972), 15-44; F. Braudel, The Identity of France. Vol. 1: History and Environment, trans. S. Reynolds (London: Collins, 1988), 312-20; R. Brunet, Les villes europeénnes (Montpellier: RECLUS, 1989); M. Broers, 'Napoleon, Charlemagne and
} 
Lotharingia: Acculturation and the Boundaries of Napoleonic Europe', The Historical Journal, 44 (2001): $135-54$.

${ }^{8}$ R. Bartlett, 'Heartland and Border: the Mental and Physical Geography of Medieval Europe', in H. Pryce and J. Watts (eds.), Power and Identity in the Middle Ages. Essays in Memory of Rees Davies (Oxford: Oxford University Press, 2007), 23-36.

${ }^{9}$ R. Parisot, Le royaume de Lorraine sous les carolingiens (843-923) (Paris: Alphonse Picard, 1898). Bégin's count is referred to by T. Bauer, Lotharingien als historischer Raum: Raumbildung und Raumbewusstsein im Mittelalter (Cologne: Böhlau, 1997), 2. Key book-length studies since Parisot include (in addition to Bauer): E. Hlawitschka, Lotharingien und das Reich an der Schwelle der deutschen Geschichte (Stuttgart: Hiersemann, 1968); W. Mohr, Geschichte des Herzogtums Lothringen (Saarbrücken: Die Mitte, 1974); M. Parisse, La noblesse Lorraine, 11e-13e siècles (Lille: Université de Lille, 1976); H.W. Herrmann and R. Schneider (eds.), Lotharingia. Eine europäische Kernlandschaft um das Jahr 1000 (Saarbrücken: SDV, 1995); J. Schneider, Auf der Suche nach dem verlorenen Reich. Lotharingien im 9. und 10. Jahrhundert (Cologne, Weimar and Vienna: Böhlau, 2010); M. Gaillard, M. Margue, A. Dierkens and H. Pettiau (eds.), De la mer du Nord à la Méditerranée: Francia Media, une région au cœur de l'Europe (c. 840-c.1050) (Luxembourg: CLUDEM: 2011). See also G. Hope, 'The Political Development of the Carolingian Kingdom of Lotharingia, 870-925', Ph.D. diss. (University of Glasgow, 2005).

${ }^{10}$ Péporté et al., Inventing Luxembourg, 112-13.

${ }^{11}$ C. Brühl, Deutschland--Frankreich: die Geburt zweier Völker (Cologne: Böhlau, 1995) offers a monumental critique of this tendency.

${ }^{12}$ T. Reuter, 'Reading the Tenth Century', in T. Reuter (ed.), The New Cambridge Medieval History vol. 3, c.900-c.1024 (Cambridge: Cambridge University Press, 1999), 1-24.

${ }^{13}$ U. Nonn, Pagus und Comitatus in Niederlothringen. Untersuchungen zur politischen Raumgliederung im früheren Mittelalter (Bonn: Röhrscheid, 1983), 54-8; M. Parisse, 'La Lotharingie: naissance d'un espace politique', in Herrmann and Schneider (eds.), Lotharingia, 31-48; M. Parisse, 'Lotharingia', in Reuter (ed.), New Cambridge Medieval History vol. 3, 310-27.

${ }^{14} \mathrm{~W}$. Haubrichs, 'La structuration linguistique de l'espace: du bilinguisme à l'émergence des frontiers', in Gaillard et al. (eds.), De la mer du nord, 41-68.

${ }^{15}$ M. Costambeys, M. Innes and S. MacLean, The Carolingian World (Cambridge: Cambridge University Press: 2011), 338-58; Alpert of Metz, De diversitate temporum, ed. H. van Rij and S. Abulafia (Amsterdam: Verloren, 1980), 2.1 and 2.21. For a translation of this text see D.S. Bachrach, Warfare and Politics in Medieval Germany, ca. 1000 (Toronto: Pontifical Institute of Mediaeval Studies, 2012).

${ }^{16}$ J. Evrard, 'Verdun, au temps de l'évêque Haymon (988-1024)', in D. Iogna-Prat and J. Picard (eds.), Religion et culture autour de l'an mil. Royaume capétien et Lotharingie (Paris: Picard, 1990, 273-8; John of St-Arnulf, Vita Johannis Gorzie, in M. Parisse (ed.), La vie de Jean, abbé de Gorze (Paris: Picard, 1999), c. 117.

${ }^{17}$ O. Bruand, 'Les centres économiques locaux dans l'espace lotharingien', in Gaillard et al. (eds.), De la mer du nord, 83-109; J.P. Devroey and N. Schroeder, 'Beyond Royal Estates and Monasteries:

Landownership in the Early Medieval Ardennes', Early Medieval Europe 20 (2012): 39-69.

${ }^{18}$ C. Dietmar and M. Trier, Colonia: Stadt der Franken. Köln vom 5. bis 10. Jahrhundert (Cologne: DuMont, 2011), 203-38.

${ }^{19}$ B. Aarts, 'Early Castles of the Meuse-Rhine Border Region and some Parallels in Western Europe c.1000: a Comparative Approach', Château Gaillard, 17 (1996): 11-23; Richer of St. Rémi, Histories, ed. and trans. J. Lake (Cambridge, Mass.: Harvard University Press, 2011), 3.6-10; M. De Waha, 'Oppida quaedam ipsorum novitia: des fortifications Lotharingiennes', in Gaillard et al. (eds.), De la mer du nord, 207-37.

${ }^{20}$ Alpert, De diversitate temporum, 2.1, 2.9.

${ }^{21}$ T. Schieffer (ed.), Die Urkunden Lothars I. und Lothars II., MGH Diplomata Karolinorum 3 (Berlin: MGH, 1966), Lothar II no. 9.

${ }^{22}$ Bauer, Lotharingien als historischer Raum, p. 1.

${ }^{23}$ On the following events see J.L. Nelson, Charles the Bald (London: Longman, 1992); E.J. Goldberg, Struggle for Empire: Kingship and Conflict under Louis the German, 817-876 (Ithaca: Cornell University Press, 2006).

${ }^{24}$ S. MacLean, 'The Carolingian Response to the Revolt of Boso, 879-87', Early Medieval Europe, 10 (2001): 21-48. 
${ }^{25}$ Regino of Prüm, Chronicle, ed. F. Kurze, Reginonis abbatis Prumiensis Chronicon cum continuatione Treverensi (Hanover: Hahn, 1890), s.a. 888. For a translation of this text see S. MacLean, History and Politics in Late Carolingian and Ottonian Europe. The Chronicle of Regino of Prüm and Adalbert of Magdeburg (Manchester and New York: Manchester University Press, 2009).

${ }^{26}$ Costambeys et al., Carolingian World, 379-427; S. Airlie, Power and its Problems in Carolingian Europe (Aldershot: Ashgate, 2012).

${ }^{27}$ M. Hartmann, 'Lotharingien in Arnolfs Reich: das Königtum Zwentibolds', in F. Fuchs and P. Schmid (eds.), Kaiser Arnolf. Das ostfränkische Reich am Ende des 9. Jahrhunderts (Munich: C.H. Beck, 2002), $122-42$.

${ }^{28}$ The implications of this are illuminated by S. Airlie, "Sad stories of the deaths of kings": Narrative Patterns and Structures of Authority in Regino of Prüm's Chronicon', in E.M. Tyler and R. Balzaretti (eds.), Narrative and History in the Early Medieval West (Turnhout: Brepols, 2006), 105-31 (the source is Adalbert's continuation of Regino's chronicle).

${ }^{29}$ The starting point for work on Charles is now G. Koziol, The Politics of Memory and Identity in Carolingian Royal Diplomas: the West Frankish Kingdom (840-987) (Turnhout: Brepols, 2012).

${ }^{30}$ P. Depreux, 'Le comte Haganon, favori de Charles le Simple, et l'aristocratie entre Loire et Rhin', in Gaillard et al. (eds.), De la mer du nord, 381-93.

${ }^{31}$ These events are best followed in Flodoard, Annales, ed. P. Lauer (Paris: Picard, 1905), which is translated in S. Fanning and B.S. Bachrach (trans.), The Annals of Flodoard of Reims, 919-966 (Peterborough, Ont.: Broadview Press, 2004).

${ }^{32}$ J. Ehlers, 'Carolingiens, Robertiens, Ottoniens: politique familiale ou relations Franco-Allemandes?', in M. Parisse and X. Barral I Altet (eds.), Le roi de France et son royaume autour de l'an mil (Paris: Picard, 1992), 39-45. Other seminal articles include B. Schneidmüller, 'Französische Lothringenpolitik im 10. Jahrhundert', Jahrbuch für westdeutsche Landesgeschichte, 5 (1979): 1-31; B. Schneidmüller, 'Regnum und ducatus. Identität und Integration in der lothringischen Geschichte des 9. bis 11. Jahrhunderts', Rheinische Vierteljahrsblätter, 51 (1987): 81-114.

${ }^{33}$ T. Reuter, Germany in the Early Middle Ages c.800-1056 (London: Longman, 1991) includes an excellent guide to Otto's reign.

${ }^{34}$ Flodoard, Annales, s.a. 959.

${ }^{35}$ Richer, Histories, 3.71; T. Riches, 'The Carolingian Sack of Aachen in 978 and its Historiographical Footprint', in P. Fouracre and D. Ganz (eds.), Frankland: The Franks and the World of Early Medieval Europe. Essays in Honour of Dame Jinty Nelson (Manchester: Manchester University Press, 2008), 191208.

${ }^{36}$ L. Falkenstein, Otto III. und Aachen (Hanover: Hahn, 1998).

${ }^{37}$ Bauer, Lotharingien als historischer Raum, 30-1; C. West, 'Lotharingia Viewed from West Francia', forthcoming.

${ }^{38}$ Parisse, 'Lotharingia', 319-24; H. Wolfram, Conrad II, 980-1039: Emperor of Three Kingdoms, trans. D. Kaiser (Pennsylvania: Pennsylvania State University Press, 2006), 56-8, 72-6, 181-3.

${ }^{39}$ Schneider, Auf der Suche, 258-9.

${ }^{40}$ J. Oberste, 'Heilige und ihre Reliquien in der politischen Kultur der früheren Ottonenzeit', Frühmittlelalterliche Studien, 37 (2003): 73-98; P. Bertrand and C. Mériaux, 'Cambrai-Magdebourg: les reliques des saints et l'intégration de la Lotharingie dans le royaume de Germanie au milieu du Xe siècle', Médiévales, 51 (2006): 85-96.

${ }^{41}$ T. Zotz, 'Carolingian Tradition and Ottonian-Salian Innovation: Comparative Perspectives on Palatine Policy in the Empire', in A. Duggan (ed.), Kings and Kingship in Medieval Europe (London: King's College London Centre for Late Antique and Medieval Studies, 1993), 69-100; S. Airlie, 'The Palace of Memory: the Carolingian Court as Political Centre', in S.R. Jones, R. Marks and A.J. Minnis (eds.), Courts and Regions in Medieval Europe (York, 2000), 1-20; M. Hare, 'Abbot Leofsige of Mettlach: an English Monk in Flanders and Upper Lotharingia in the Late Tenth Century', Anglo-Saxon England, 33 (2004): $109-44$, at $125-7$

${ }^{42}$ This point is developed in S. MacLean, 'Palaces, Itineraries and Political Order in the Post-Carolingian Kingdoms', in J. Hudson and A. Rodriguez (eds.), Diverging Paths (forthcoming). 
${ }^{43}$ On the historiographical issue see Brühl, Deutschland-Frankreich; P.J. Geary, The Myth of Nations: the Medieval Origins of Europe (Princeton: Princeton University Press, 2002). On the historical context, the contributions to Reuter (ed.), New Cambridge Medieval History vol. 3 are the best starting point.

${ }^{44}$ For example: F. Steinbach, 'Gibt es einen lothringischen Raum', Rheinische Vierteljahrsblätter, 9 (1939): 52-66.

${ }^{45}$ For further references see S. MacLean, 'Apocalypse and Revolution: Europe around the Year 1000', Early Medieval Europe, 15 (2007): 86-106.

${ }^{46}$ C. West, 'Principautés et territories: comtes et comtés', in Gaillard et al. (eds.), De la mer du nord, 13150 is an excellent recent contribution, to be expanded in the author's forthcoming book.

${ }^{47}$ T. Riches, 'The Changing Political Horizons of Gesta Episcoporum from the Ninth to Eleventh Centuries', in L. Körntgen and D. Waßenhoven (eds.), Patterns of Episcopal Power. Bishops in Tenth and Eleventh Century Western Europe (Berlin and Boston: De Gruyter, 2011), 51-62.

${ }^{48}$ Reuter, 'Reading the Tenth Century'. The jigsaw metaphor is stolen from S. Keynes. 'England, 9001016', in Reuter (ed.), New Cambridge Medieval History vol.3, 456-84.

${ }^{49}$ T. Schieffer (ed.), Die Urkunden Zwentibolds und Ludwigs des Kindes, MGH Diplomata Regum Germaniae ex Stirpe Karolinorum IV (Berlin: Weidmann, 1960), Louis the Child no. 20.

${ }^{50}$ Flodoard, Annals, s.a. 953.

${ }^{51}$ E. Boshof, 'Lotharingien-Lothringen. Vom Teilreich zum Herzogtum', in E. Boshof and H.H. Anton (eds.), Zwischen Gallia und Germania, Frankreich und Deutschland (Trier: Trierer Historiche Forschungen, 1987), 129-53 at 146.

${ }^{52}$ H.W. Goetz, Dux und Ducatus: Begriffs- und verfassungsgeschichtliche Untersuchungen zur Entstehung des sogenannten jüngeren Stammesherzogtums an der Wende vom 9. zum 10. Jahrhundert (Bochum:

Brockmeyer, 1977). See also the excellent M. Becher, Rex, Dux und Gens. Untersuchungen zur Entstehung des sächsischen Herzogtums im 9. und 10. Jahrhundert (Husum: Matthiesen, 1996).

${ }^{53}$ R. Barth, Der Herzog in Lotharingien im 10. Jahrhundert (Sigmaringen: Thorbecke, 1990); Schneider, Auf der Suche.

54 J. Halkin and C.G. Roland (eds.), Recueil des chartes de l'abbaye de Stavelot-Malmedy (Brussels: Hayez, 1909), no. 61.

55 A. Dierkens and M. Margue, 'Memoria ou damnatio memoriae? L'image de Giselbert, duc de Lotharingie (†939)', in S. Gouguenheim et al. (eds.), Retour aux sources. Textes, études et documents d'histoire médiévale offerts à Michel Parisse (Paris: Picard, 2004), 869-90.

${ }^{56}$ E. Hlawitschka, 'Herzog Giselbert von Lothringen und das Kloster Remiremont', Zeitschrift für die Geschichte des Oberrheins, 108 (1960): 422-65.

${ }^{57}$ Vita Johannis Gorzie, cc. 99, 104-14.

${ }^{58}$ J. Nightingale, Monasteries and Patrons in the Gorze Reform: Lotharingia, c.850-1000 (Oxford: Oxford University Press, 2001).

${ }^{59}$ Flodoard, Annals, is the best guide to these events.

${ }^{60}$ P. Nissen and V. Hunink (ed. and trans.), Vita Radboudi (Nijmegen: Radboud University, 2004), c.6. On the date, see E. Karpf, Herrscherlegitimation und Reichsbegriff in der ottonischen Geschichtsschreibung des 10. Jahrhunderts (Stuttgart: Steiner, 1985), 98-101.

${ }^{61}$ M. Parisse, 'Les hommes et le pouvoir dans la Lorraine de l'an mil', in Iogna-Prat and Picard (eds.), Religion et culture, 259-66; Parisse, 'Lotharingia'.

${ }^{62}$ On reification in Lotharingian offices see West 'Principautés et territories'.

${ }^{63}$ Miracula sancti Gorgonii, in M. Goullet, M. Parisse and A. Wagner (eds.), Sources hagiographiques de l'histoire de Gorze (Paris: Picard, 2010), cc. 20-2.

${ }^{64}$ A. Lesort (ed.), Chronique et chartes de l'abbaye de Saint-Mihiel (Paris: Klincksieck, 1909-12), c. 7.

${ }^{65}$ Political titles are discussed at length by Bauer, Lotharingien als historischer Raum, 43-68; Schneider, Auf der Suche, 124-48.

66 There are many good discussions of this vocabulary: the most recent, with references to older works, is Schneider, Auf der Suche, 258-73.

${ }^{67}$ Widukind, Rerum Gestarum Saxonicarum Libri Tres, ed. P. Hirsch, MGH SRG (Hanover: Hahn, 1935), 1.30 and 2.36 .

${ }^{68}$ T. Reuter, 'Whose Race, Whose Ethnicity? Recent Medievalists' Discussions of Identity', in T. Reuter, Medieval Polities and Modern Mentalities, ed. J.L. Nelson (Cambridge: Cambridge University Press, 2006), 100-8. 
${ }^{69}$ See MacLean, History and Politics, 188-9.

${ }^{70}$ T. Schieffer, 'Die lotharingische Kanzlei um 900', Deutsches Archiv, 14 (1958): 16-148; H. Anton, 'Synoden, Teilreichsepiskopat und die Herausbildung Lotharingiens (859-870)', in G. Jenal (ed.), Herrschaft, Kirche, Kultur. Beiträge zur Geschichte des Mittelalters. Festschrift für Friedrich Prinz (Stuttgart: Hiersemann, 1993), 83-124; I. Voss, 'La Lotharingie, terre de rencontres Xe-XIe siècles', in Iogna-Prat and Picard (eds.), Religion et culture, 267-72; T. Bauer, 'Die Francia Media: ein Land der Begegnung', in Gaillard et al. (eds.), De la mer du nord, 357-80.

${ }^{71}$ Bauer, Lotharingien als historischer Raum.

${ }^{72}$ S. Airlie, 'Unreal Kingdom: Francia Media under the Shadow of Lothar II', in Gaillard et al. (eds.), De la mer du nord, 339-56.

${ }^{73}$ On the text see especially Airlie, "'Sad stories of the deaths of kings"'.

${ }^{74}$ Schneider, Auf der Suche; M. Margue, "Nous ne sommes ni de l'une, ni de l'autre, mais les deux à la fois". Entre France et Germanie, les identités lotharingiennes en question(s)', in Gaillard et al. (eds.), De la mer du nord, 395-427. Hope, 'Political Development' offers a nuanced, but also sceptical, account.

${ }^{75}$ Margue, "Nous ne sommes ni de l'une, ni de l'autre”, 421-6.

${ }^{76}$ M. Innes, 'Historical Writing, Ethnicity, and National Identity: Medieval Europe and Byzantium in Comparison', in S. Foot and C.F. Robinson, The Oxford History of Historical Writing vol. 2, 400-1400 (forthcoming).

${ }^{77}$ J. Ehlers, 'Karolingische Tradition und frühes Nationalbewusstsein in Frankreich', Francia, 4 (1976): 213-35; Brühl, Deutschland-Frankreich, 97-125; Becher, Rex, dux und gens; E. Müller-Mertens, 'Frankenreich oder Nicht-Frankenreich? Überlegungen zum Reich der Ottonen anhand des Herrschertitels und der politischen Struktur des Reichs', Historische Zeitschrift. Beihefte N. S., 24 (1997): 45-52.

${ }^{78}$ Reuter, 'Whose Race, Whose Ethnicity?'

${ }^{79}$ Acknowledgements: Conan Fischer and Charles West. 